\title{
The Construction Process of Pedagogical Knowledge among Nursing Professors $^{1}$
}

\author{
Vânia Marli Schubert Backes² \\ Jose Luis Medina Moyá ${ }^{3}$ \\ Marta Lenise do Prado ${ }^{4}$
}

\begin{abstract}
Didactic knowledge about contents is constructed through an idiosyncratic synthesis between knowledge about the subject area, students' general pedagogical knowledge and the teacher's biography. This study aimed to understand the construction process and the sources of Pedagogical Content Knowledge, as well as to analyze its manifestations and variations in interactive teaching by teachers whom the students considered competent. Data collection involved teachers from an undergraduate nursing program in the South of Brazil, through non-participant observation and semistructured interviews. Data analysis was submitted to the constant comparison method. The results disclose the need for initial education to cover pedagogical aspects for nurses; to assume permanent education as fundamental in view of the complexity of contents and teaching; to use mentoring/ monitoring and the value learning with experienced teachers with a view to the development of quality teaching.
\end{abstract}

Descriptors: Nursing; Education, Higher; Faculty; Teaching.

\footnotetext{
${ }^{1}$ This research was supported by Conselho Nacional de Desenvolvimento Científico e Tecnológico (CNpq), process \# 201130/2009-2.

${ }^{2}$ RN, Ph.D. in Nursing, Associate Professor, Departamento de Enfermagem, Universidade Federal de Santa Catarina, Florianópolis, SC, Brazil. E-mail: oivania@ccs.ufsc.br.

3 Ph.D. in Philosophy and Education Sciences, Full Professor, Faculdade de Pedagogia, Universidade de Barcelona, Spain. E-mail:jlmedina@ub.edu.

${ }^{4}$ RN, Ph.D. in Nursing, Associate Professor, Departamento de Enfermagem, Universidade Federal de Santa Catarina, Florianópolis, SC, Brazil. E-mail: mpradop@ccs.ufsc.br.
}

Corresponding Author:

Vânia Marli Schubert Backes

Rua Victor Konder, 54/303, Edifício Constant

Bairro: Centro

CEP: 88015-400, Florianópolis, SC, Brasil.

E-mail: oivania@ccs.ufsc.br 


\section{Processo de construção do conhecimento pedagógico do docente universitário de enfermagem}

O conhecimento didático do conteúdo se constrói mediante a síntese idiossincrásica entre o conhecimento da disciplina, o conhecimento pedagógico geral e o conhecimento dos alunos e também a biografia do professor. O estudo teve como objetivos compreender o processo de construção e as fontes do Conhecimento Didático do Conteúdo e analisar as suas manifestações e variações, no ensino interativo de docentes considerados competentes pelos estudantes. Os dados foram coletados junto a docentes de um curso de graduação em Enfermagem da Região Sul do Brasil, por meio de observação não participante e entrevista semiestruturada. A análise dos dados foi submetida ao método de comparações constantes. Os resultados evidenciam a necessidade de contemplar, na formação inicial, aspectos pedagógicos aos enfermeiros, tomar a formação permanente como essencial diante da complexidade do conteúdo e do ensino, usar o mentoring/ monitoramento e a valorização da aprendizagem com docentes experimentados, para o desenvolvimento do ensino com qualidade.

Descritores: Enfermagem; Educação Superior; Docentes; Ensino.

\section{Proceso de construcción del conocimiento pedagógico del docente universitario de enfermería}

El conocimiento didáctico del contenido se construyó mediante una síntesis idiosincrática entre el conocimiento de la disciplina, el conocimiento pedagógico general y el conocimiento de los alumnos y también la biografía del profesor. El estudio tuvo como objetivos comprender el proceso de construcción y las fuentes del Conocimiento Didáctico del Contenido y analizar sus manifestaciones y variaciones en la enseñanza interactiva de docentes considerados competentes por los estudiantes. Los datos fueron recolectados junto a docentes de un curso de graduación en Enfermería de la Región Sur de Brasil, por medio de observación no participativa y entrevista semiestructurada. El análisis de los datos fue sometido al método de comparaciones constantes. Los resultados evidencian la necesidad de contemplar, en la formación inicial, aspectos pedagógicos para los enfermeros; considerar la formación permanente como esencial delante de la complejidad del contenido y de la enseñanza; usar el mentoring/monitorización y la valorización del aprendizaje con docentes expertos para el desarrollo de la enseñanza con calidad.

Descriptores: Enfermería; Educación Superior; Docentes; Enseñanza.

\section{Introduction}

Teaching is a complex social practice that combines knowledge, skills, attitudes, expectations and worldviews conditioned by teachers' different life histories. It also receives Strong influence from the culture of the institutions $^{(1)}$ where it is accomplished. When confronted with practice and the concrete conditions and requirements of the profession, teachers are continuously producing specific, tacit, personal and non-systemized knowledge which, related to other knowledge types, becomes part of their identity as teachers ${ }^{(2)}$, constituting important elements in pedagogical practices and decisions and also renewing their conception of teaching and learning ${ }^{(3)}$.

In this perspective, national movements like the establishment of the National Curricular Guidelines(4), as well as international movements and the creation of the European Higher Education Area (Bologna Process) (5) were organized to promote significant changes in education processes. These paradigmatic and structural 
changes propose, among many aspects, new teaching methods centered on student learning; a new conception of teaching work, able to stimulate students, provoking significant learning, reflexive and critical thinking skills, learning to learn through the review of professional exercise $^{(6-7)}$.

Studies about teachers' knowledge( ${ }^{(1)}$ have turned into a fruitful and recently consolidated research area. School, the teaching profession and teachers' initial and permanent education (2) are also analyzed, as they offer elements to abandon the traditional, academic or encyclopedist teacher concept, whose primordial function is knowledge transmission, mechanically and prescriptively applying intervention procedures that were planned and offered externally.

Thus, studying Pedagogical Content Knowledge provides evidence on how these transformations take place. In this perspective, Lee Shulman has been the pioneer to define and conceptualize the "baseline" knowledge teachers need for competent teaching practice. To explain the elaboration and usage process of didactic knowledge about contents, the expert( ${ }^{(8)}$ proposes his Pedagogical Reasoning and Action Model. According to this model, more or less knowingly, teachers transform the contents into something teachable and understandable for the students. After determining what contents to teach, the teachers transform it, selecting what material to use, examples and analogies, explanations and metaphors with a view to adapting the contents to the students, in view of their interests, prejudices, age, among others. This process implies an understanding that is neither exclusively technical nor reflexive. It is not only content knowledge, nor the mastering of didactic techniques. Instead, it is a pedagogically oriented mixture of all of these elements.

This study aimed to understand the construction process and sources of Didactic Knowledge about Contents in interactive teaching in function of three moments in teachers' professional trajectory: new, intermediary and experienced.

\section{Method}

This is a descriptive, exploratory and analytic qualitative research. Exploratory-analytic research is intended to understand the reasons and motivations implied in certain attitudes and behaviors of people/ phenomena, enhancing the formation of ideas to understand the problem as a whole, put in practice through an in-depth analysis of the findings ${ }^{(9)}$. The research complied with the ethical standards of National Health Council Resolution 196/96. Approval was obtained from the Institutional Review Board under process number 184/09.

The research subjects were 03 faculty from the Undergraduate Nursing Program at a federal university in the South of Brazil, respectively, one considered a novel (between 01 and 05 years of experience); one intermediary (between 06 and 14 years) and one experienced (more than 15 years of teaching experience in higher education). To preserve anonymity, the teachers received codenames: Hortênsia, Rosa and Margarida, respectively. The subject selection was based on an intentional sample ${ }^{(10)}$, which involves determining the characteristics of the subjects who will participate in the research with a view to obtaining all necessary information for the study problem. The participating faculty members were identified through a survey among the 35 lastyear students, who indicated a faculty member they considered a good teacher during their education process, either due to his/her acknowledged preparation and mastery of teaching contents, ability to motivate students for learning, commitment to the improvement and innovation of university teaching and the achievement of good results with their students. Therefore, the students answered two questions, one naming the teachers from whom they learned most and the second stating why. Thus, the subjects were selected, who were contacted and accepted to participate in the study.

Non-participant observation of the college teachers who served as the research subjects was used for data collection. The classes were audio and video-recorded and the researchers also made field notes. One session was observed for each teacher, lasting 03 hours each. The semistructured interview with the teachers served to obtain information on the intentions, objectives and didactic method the teachers planned for each of the class sessions.

Data analysis was submitted to the constant comparison method(10). This strategy combines the coding of inductive categories with a simultaneous comparison process of all social events observed. When constantly comparing events or detected phenomena with previous ones, new typological dimensions and new relations can be discovered, resulting in new knowledge. Finally, the findings were interpreted and discussed, triangulating data at each moment in the teaching career (novel, intermediary and experienced) and in the light of the theoretical framework of Pedagogical Content Knowledge ${ }^{(11)}$ and its constituent elements ${ }^{(1)}$. 
Thus, two core categories were constructed according to the theoretical background and research goals: a) Sources of Pedagogical Content Knowledge and elements of learning from experienced colleagues: learning in and about practice; pedagogical training; mentoringmonitoring; resources and material for teaching; and b) the Interactive Teaching Process with the elements: presence of reflexive dialogue; use of analogies, examples and anecdotic histories; expression of expert thinking and disciplinary integration; pedagogical empathy; perception patterns; transference and conclusion actions and feedback from classes.

\section{Results}

Pedagogical Content Knowledge, the focus of this research, serves the express the different types of knowledge and skills teachers use to transform their knowledge about the subject into actual pedagogical representations $^{(11-12)}$.

Thus, regarding the Sources of Pedagogical Content Knowledge, Margarida is a teacher with more than 25 years of teaching, and is hence considered an experienced teacher in this study. Seen after the graduated in Nursing, she took a Specialization Course in Higher Education Methodology. When she became a faculty in an Undergraduate Nursing Program, she was left in charge of the subject Didactics Applied to Nursing. She pursued with a Master's and Ph.D. Program in Education. Various teachers of hers were students of the educator Paulo Freire, and she also had the opportunity to study with Freire in permanent education courses. She mentions applying Freire's teaching in her teaching practice, promoting dialogue and committed participation and seeking permanent recycling. She has been responsible for the subject Alternative Therapies for 05 years. Margarida demonstrates content knowledge and highlights the importance of the subject in the curriculum and in professional education.

I took higher education methodology ... which was a specialization course, and as a result of this same specialization course, I started to bother with the way I gave classes. Of course, because when you start, you start based on the models you had, giving presentations, course books, giving this, giving that, I used to work in quite a dense subject. I took them to the hospital, the subject was very heavy and it ended up being very traditional (Margarida).

Rosa has been a teacher for 10 years and, in the research, she is qualified as an intermediary teacher. She holds an undergraduate Nursing degree and no special teaching diploma. She started to like teaching as a clinical nurse in a teaching hospital, who received students and teachers in her professional activity area. This approximation strengthened her and she started to work as a teacher at a private teaching institution in an area different from hers. She mentions having studied a lot to handle the new area and cites the use of feedback from her classes as an important selfassessment resource. When she took her Master's in Nursing and read about education, especially Paulo Freire, she says she changed her way of interacting with the student and conducting her classes. She perceived that she initially followed the traditional model, as she assimilated and reproduced the knowledge to the students. She highlighted the importance of putting herself in the student's place. Some other experiences, including contact with Active teaching Methods in a permanent education course, served to strengthen new postures. She considers the subject she teaches, which is surgical patient care, important for students, and the contents addressed in the observed session discussed Ethics, Moral and Bioethics. She demonstrated content knowledge and participatory management.

In the Master's program, we got a course about Paulo Freire, so those readings I did and I have that very thin book of his, the pedagogics of autonomy. So, I attempt to use that philosophy of his ... that philosophy of looking at what that student knows, of valuing what he brings to add, I have a lot of that too. My preparation as a teacher is based on Paulo Freire and I got that in the Master's program (Rosa).

Hortênsia graduated in Nursing and is a novel teacher, with 05 years of experience. She tells that as early as in her undergraduate program, when she performed interactive health education activities that involved adolescents, she used her intuition to get closer to the students and construct knowledge with them. She reveals that, at that moment, she did not know Paulo Freire's teaching and that, until today, she is getting to know his method better. After graduation, she started to work as a clinical nurse and secondary education teacher. She had the opportunity to work in a Distance Education project using the problemization method. Today, she is taking her Ph.D. program and working as a substitute teacher in a Nursing program. She teaches in the subject where students get into the hospital environment for this first time and deliver comprehensive patient care. She is aware of the importance of this subject in Nursing education and constantly puts herself in the students' place, as she remembers what it was like when she was a student and, thus, knows what is best for the students' 
learning. She takes permanent education courses and served as a voluntary teacher to participate in the setup of active methods in the subject. The content she addressed during the observed session discussed Ethics and Interpersonal Relations in care practice. She applied teaching-learning dynamics and dialogue to promote the class, demonstrating content knowledge.

My trajectory as a teacher started long before I became a nurse. I was in the fifth grade and we had a community activity... we prepared that traditional class, of course... the way we learned, we also wanted to teach... In the middle of the discussion the students started to move around in the classroom and got dispersed... I got a light from above and said - come one, let's sit on the floor, because I imaged that, if we sat on the floor it would be calmer to talk, because it was a complicated topic, about pregnancy and things. That already started to destroy all of that planning we had made... when I made that move, those students from a poor community, nobody had ever talked to them about that, they opened up, then they started - what's that, masturbating? ... I didn't even remember what was in my planning, what was in the slide series... and I started to explain, that's normal, and various questions came up and I relaxed, so did the students. Then it turned into a talk and that was very good (Hortênsia).

Evidence about the Interactive Teaching Process refers to the class session that was observed and audio and video-recorded.

Margarita's session took the form of a Seminar, presented by the student group responsible for contents on alternative therapies. The students, sitting in circles, presented the contents and the teacher intervened to ask questions and inquiries, making them establish relations with passed contents, made references to literature and also added examples, anecdotes and emphasized usage relations in current practice and in students' professional life. She called the students by their names and took their opinion into account. The students demonstrated their interest, some talked about the use and application of some alternative therapy mode.

It is always strongly highlighted that academic students won't graduate with competencies to develop any of these therapies, but he'll be able to understand that these other possibilities exist, so that they can seek the necessary knowledge when they finish the course, many students already seek courses on traditional Chinese medicine during the subject, on Reiki, it's a very interesting movement (Margarida).

Rosa offered a dialogued presentation that included data-show. She demonstrated content mastery, cited literature, questioned the students, provoked their participation and established content relations through example experiences, anecdotes and talked a lot about the contents' importance in the program and professional life. She called students by their names.

Look at the last phrase here: Ethics is a rational attempt to verify and live together better. Then we get back to the story about clinical research, about the technology we have at our disposal. I ask you, is technology something good or something bad? Students- That depends on how I'm gonna use it. TeacherIf it depends on how I'm gonna use it, let me ask the question again: is technology something good or something bad? Students- Both or none. Teacher- Because goodness is not part of the technology, but of who uses it. Then we reach another issue. Is man an end or a means? In technology, I use man as a means or an end? If I use him as an end, I use technology to his benefit, if I use him as a means, technology is my end. Who serves whom? Does technology serve man or does man serve technology? Student- It is man who will decide if he's gonna use technology as an instrument (Rosa).

Hortênsia used integrative dynamics with students, provoking their immediate participation. The contents were more restricted to the students' current practical experiences before the assessment itself. She called students by their names and used her own examples, anecdotes and related the contents with students' future perspectives, but did not make reference to the contents in the curriculum as a whole. She neither presented nor discussed this perspective. The aspects illustrated in one of her examples, however, transmit the exact dimension of the difference and, at the same time, of the necessary complementariness between content knowledge and pedagogical content knowledge.

We can discuss what's in the book, but bring a complementary paper. One month went by, I said -class, it's so strange that nobody brought the book anymore - we couldn't, Miss, it limits a lot, we don't manage to see other things. That's how you see your work, the student grows a lot through that. Then they said Miss, I think we'll have to close a new deal. -What deal? -Let's bring 2 papers each day? Then we set up a group e-mail that stores papers, they like to search. Sometimes I stop, I see that they don't manage to search... let's organize an internet class here, let's see the databases?... then they start to glimpse a new world. That method grants us this flexibility (Hortênsia).

\section{Discussion}

As for the Sources of PCK, the three faculty mentioned and demonstrated learning in and about practice ${ }^{(13-14)}$, reflecting and planning the best way to teach the contents, actively interacting with students in class. They considered the correction of tasks an important moment. 
The experienced teacher Margarida evidenced aspects like learning from experienced colleagues, influence of and search for permanent education closer to teaching, in the Education area itself. The other two, Rosa and Hortênsia, did not get specific education that comprised teacher training, but merely permanent education experiences to support this preparation.

Margarida, at the same time as she highlights her permanent education, preparing her for teaching, exposes the lack of pedagogical preparation in initial professional education. Therefore, the knowledge source based on the reproduction of pedagogical models experienced during education was mentioned, in line with findings from other Brazilian studies ${ }^{(15-17)}$. This justifies the need for specific training in the teaching area as well. The teachers highlighted permanent education and support or advice from a veteran teacher as ideas implied in the construction of pedagogical content knowledge(18).

This aspect has been systematically emphasized in research ${ }^{(8,12)}$, and one example is the case of Nancy, pictured as an expert teacher. This means that, besides her updated theoretical mastery, she has situational awareness about the development of her teaching activities, capacity and skills to reflect in action and about the action developed in the teaching-learning process involving older teachers. In this study, it is perceived that the teachers consider this professional socialization an important source for their pedagogical content knowledge. This aspect is not present in other Brazilian studies on the teaching preparation of nurse teachers ${ }^{(15,19-20)}$, indicating the need for an important reflection in the context of initial and permanent education for nursing faculty. The scarce studies on the preparation of Nursing faculty mark the great challenge faced in this area, created the need to strengthen this research line on this important emerging line.

The use of intuition and her beliefs the novel teacher Hortênsia mentioned was remarkable. This fact is in line with studies(11-12) that have identified intuition as an important element for the teaching process and present in teachers' culture and personal context. They indicate that the teachers' beliefs on teaching and learning are related with how they consider teaching, how they learn from their experiences and how they behave in their classes.

Beliefs depend much more on subjective-affective and personal than on objective assessment and are also more discussible, open than knowledge, which depends on evidenced criteria for its incorporation. Therefore, the same authors recommend the valuation of opportunities for new teachers to identify and examine their beliefs about the contents they teach and their influence on the way they teach.

None of the teachers evidenced or remembered mentoring/monitoring or accompaniment in the initial phase of teaching. These findings lead to the belief that no mentoring practice exists, nor valuation of learning from experienced faculty ${ }^{(11)}$. Thus, the opportunity is lost for learning and socialization with experienced teachers, who tend to be experts in content knowledge and pedagogical content knowledge and, thus, the possibility of innovating the teaching-learning process in a safe, critical and reflected way.

The Interactive Teaching Process captured while observing the classes entailed important considerations. Reflexive dialogue, anecdotes, examples and analogies used constantly and coherently entailed light and significant learning. The teachers also readily responded to and sensitively addressed the fast and insightful perception of some student(s)'s difficulties or lack of interest, as well as transference, i.e. the application of strategies to explore and articulate the contents with a view to future professional practice.

Elements like the competent expression of the cognitive/theoretical model present in the abstract contents and its concrete articulation with professional reality, however, as well as the use of pedagogical inquiries - different strategies to achieve the course objectives and students' participation, disciplinary integration and content conclusion actions - were brilliantly present in Margarida, the experienced teacher's class. Pedagogical inquiry ${ }^{(12)}$ is associated with new knowledge acquisition, either about pedagogics or contents, and demands, among others, skills to reflect on and learn from experience, an aspect evidenced in the research. Margarida's propriety in managing the contents and the forms to understand it are similar to the teachers who admire Nancy's teaching ${ }^{(11)}$, enhancing a learning process about simpler aspects, creatively evolving to more complex ones. This matter is directly related with the teacher's content knowledge and directly affects the instruction style, which can demonstrate, with more or less security, critical content management with a view to students' involvement in the teaching-learning process ${ }^{(12)}$.

The teaching time-experience ${ }^{(18)}$ is addressed as a situation that allows teachers to redefine their content knowledge and construct pedagogical knowledge, suggesting the ability to perceive their disciplinary unit in a broader sense in terms of curriculum and, at the same time, turns into an important elements in 
pedagogical knowledge development. The teachers Rosa and Hortênsia's explanation should also be highlighted, when they mention the importance of putting oneself in the student's place, that is, the use of pedagogical empathy. This is something teachers forget to do when remembering that they have already occupied the place students are in today and know about the difficulties felt in view of contents or experienced situations. The influence of the educator Paulo Freire was unanimous among the three faculty, permitting a critical-reflexive and participatory base in their teaching activities, strengthened by critical dialogue, attentive listening and stimulating the student's active participation.

Hence, the teaching process needs to start in a circumstance where the teachers understand what needs to be learned and how they should teach it.

\section{Conclusions}

The researcher does not want to conclude this research with a simple declaration on standardized teaching behaviors that can be generalized to the higher education teaching profession, but to study teaching based on the teachers' knowledge, instead of focusing on information processing about the teachers' knowledge.

Therefore, some theoretical and operational key ideas are offered to the higher Nursing education community, which permit excellence in teaching, as well as ideas that concretely distinguish experienced/expert teachers from teachers who do not manage to achieve good results with their students.

Although teaching is one of the most ancient professions in the world, the systematic study of teaching, especially considering professional teachers, is recent. Thus, to the extent that more is learned about teaching, new categories of performance and understanding will be acknowledged which characterize good teachers, permitting the reconsideration and redefinition of other spheres. These include the need and importance of covering pedagogical aspects for nurses in initial education; the assumption of permanent education as a necessary condition in view of the competence and complexity of contents and teaching and mastery to express expert thinking, improve pedagogical inquiries and disciplinary/curricular integration, which makes the difference in teaching. Also, the use of mentoring/ monitoring is highlighted, as well as the valuation of learning from experienced teachers with a view to the development of high-quality teaching.

\section{References}

1. Borrasca BJ. Conocimiento profesional y buenas prácticas en la educacíon superior: genesis y influencias mutuas entre los saberes disciplinares y pedagógicos del profesorado universitario [tese de doutorado]. Barcelona: Universitat de Barcelona; 2008.

2. Imbernón F. Formação docente e profissional formar-se para a mudança e a incerteza. São Paulo (SP): Cortez; 2002. 253 p.

3. Tardif M. Saberes docentes e formação profissional. Petrópolis (RJ): Vozes; 2002.

4. Resolução CNE/CES n. ${ }^{\circ}$ 3, de 7 de novembro de 2001 (BR). Institui Diretrizes Curriculares Nacionais do Curso de Graduação em Enfermagem. Diário Oficial da União 9 nov 2001. p. 37

5. Bologna Process [internet]. Website of the European Higher Education Area [acesso: 15 mar 2009]. Disponível em: www.bologna2009benelux.org

6. Freire P. Pedagogia da Autonomia: saberes necessários à prática educativa. 37.ed. Rio de Janeiro: Paz e Terra; 2008. 165 p.

7. Faria JIL, Casagrande LDR. Education for the XXI century and the reflexive teacher's formation nursing. Rev. Latino-Am. Enfermagem. 2004;12(5):111-8.

8. Shulman LS. Tose who understand: knowledge growth in teaching. Educ Res. 1986;15(2):4-14.

9. Creswell JW. Research Design: Qualitative and Quantitative approaches. Thousand Oaks: SAGE; 1998. 264 p.

10. Goetz JP, LeCompte MD. Etnografia y diseño cualitativo en investigación educativa. Madrid: Ediciones Morata; 1988. $279 \mathrm{p}$

11. Shulman LS. Conocimiento y enseñanza: fundamentos de la nueva reforma. Profesorado. Rev Curriculum Formación Profesorado [internet]. 2005 [acesso: 23 mar 2009];9(2). Disponível em: http:// www.ugr.es/ recfpro/?p=235

12. Grossman PL, Wilson SM, Shulman, LS. Profesores de sustancia: el conocimiento de la material para la enseñanza. Profesorado. Rev Curriculum Formación Profesorado. [internet]. 2005 [acesso: 23 mar 2009];9(2). Disponível em: http://www.ugr.es/ recfpro/?p=235

13. Moya JLM, Parra SC. La enseñanza de La enfermería como una práctica reflexiva. Texto Contexto Enferm. 2006;15(2):303-11.

14. Schon DA. Educando o profissional reflexivo: um novo design para o ensino e a aprendizagem. Porto Alegre: Artmed; 2000. 255 p. 
15. Rodrigues MTP, Mendes JAC Sobrinho. Obstáculos didáticos no cotidiano da prática pedagógica do enfermeiro professor. Rev Bras Enferm. 2008;61(4):435-40.

16. Batista NA. Desenvolvimento docente na área da saúde: uma análise. Trabalho Educ Saúde. 2005;3(2):283-94.

17. Costa NMSC. Pedagogical training of medicine professors. Rev. Latino-Am. Enfermagem. 2010;18(1):102-8.

18. Gudmundsdottir S, Shulman LS. Conocimiento didatico en ciencias sociales. Profesorado. Rev Curriculum Formación Profesorado. [internet]. 2005 [acesso: 23 mar 2009];9(2). Disponível em: http:// www.ugr.es/ recfpro/?p=235

19. Madeira MZA, Lima MGSB. A prática de ensinar: dialogando com as professoras de enfermagem. Rev Bras Enferm. 2008;61(4):447-53.

20. Ferreira MA Junior. Os reflexos da formação inicial na atuação dos professores enfermeiros. Rev Bras Enferm. 2008;61(6):866-71. 